\title{
Systemic inflammatory and stress markers in cattle and sheep submitted to different reproductive procedures
}

\author{
Vitória Gasperin Guazzelli Costa ${ }^{1}$ Arnaldo Diniz Vieira ${ }^{1}$ Augusto Schneider $^{1}$ (?) \\ Monique Tomazele Rovani ${ }^{1}$ Paulo Bayard Dias Gonçalves ${ }^{2,3}$ Bernardo Garziera Gasperin $^{{ }^{*}}$
}

${ }^{1}$ Faculdade de Veterinária, Universidade Federal de Pelotas (UFPel), Campus Universitário, 96010-900, Capão do Leão, RS, Brasil. E-mail: bggasperin@gmail.com. "Corresponding author.

${ }^{2}$ Programa de Pós-graduação em Bioquímica, Programa de Pós-graduação em Ciência Animal, Universidade Federal do Pampa (Unipampa), Campus Uruguaiana, RS, Brasil.

${ }^{3}$ Programa de Pós-graduação em Medicina Veterinária, Universidade Federal de Santa Maria (UFSM), Santa Maria, RS, Brasil.

ABSTRACT: Previous studies have evaluated the effects of different reproductive procedures on discomfort markers in sheep and cattle Such studies may help stimulate the adoption of techniques that are more beneficial for animal welfare. However, markers that are commonly used to evaluate discomfort are highly influenced by external factors. To overcome this, several systemic markers can be evaluated to more precisely identify stress, pain, and inflammation. Such markers include cortisol, acute phase proteins, bradykinin, and substance P. We aimed to review the potential markers of stress, pain, and inflammation, and discuss how and when they are regulated after different stimuli related to reproductive procedures in cattle and sheep. Furthermore, we aimed to review how reproductive procedures with different degrees of invasiveness cause stress and provide information that may help develop strategies to limit animal discomfort.

Key words: acute phase proteins, cortisol, discomfort, reproductive techniques.

Marcadores sistêmicos de inflamação e estresse em bovinos e ovinos submetidos a diferentes procedimentos reprodutivos

RESUMO: Estudos anteriores avaliaram o efeito de diferentes procedimentos reprodutivos sobre marcadores de desconforto em bovinos e ovinos. Tais estudos podem estimular a adoção de técnicas que preservem o bem-estar animal. Entretanto, os marcadores comumente utilizados apresentam alta influência de fatores externos. Para contornar isso, a avaliação conjunta de diferentes parâmetros sistêmicos pode ser utilizada para determinar com maior precisão a presença de estresse, dor ou inflamação, como cortisol, proteinas de fase aguda, a bradicinina e a substância P. O objetivo desta revisão é relacionar potenciais marcadores de inflamação e estresse, discutindo como e quando são regulados frente aos estímulos em bovinos e ovinos. Ainda, pretende-se revisar de que forma procedimentos reprodutivos com diferentes graus de invasividade acarretam em desconforto, fornecendo informações para a elaboração de estratégias que possibilitem minimizá-lo. Palavras chave: biotécnicas da reprodução, cortisol, desconforto, proteinas de fase aguda.

\section{INTRODUCTION}

Intensification of livestock production to supply global demand for animal protein can conflict with animal welfare principles. Conversely, the demand for products from farms that prioritize animal comfort and well-being is increasing (HEID \& HAMM, 2013). This stimulates the adoption of good farming practices in animal production, because the benefits outweigh the costs (BENNETT \& BLANEY, 2003).

Although the consumers understand that farmers adopt certain practices for economic reasons (SPOONER et al., 2014), the responsibility for meeting animal welfare standards is attributed to producers, animal husbandry technicians and veterinarians. Therefore, it is necessary to improve animal husbandry practices that promote animal comfort. Such practices should be based on scientific evidence that can be repeated under different circumstances and by different investigators. To achieve this goal, the critical moments and situations in the lives of farm animals must be identified. To do so, the scientific literature suggests some models based on behavioral and physical traits, such as the 'Five Domains Model', which estimates an animal's welfare condition based on comprehensive and coherent assessment (MELLOR, 2017).

When evaluating animal welfare, to ensure the reproducibility of the obtained data, it is necessary 
to consider criteria that are well validated, suitable, and accurate. The evaluation of animal welfare cannot be only subjective, and, for that reason, there are objective physiological and behavioral parameters that can be assessed using previously developed methods, which allow us to better understand the animals' responses to different situations (BLACHE \& MALONEY, 2017). It is possible to assess welfare parameters using behavioral observations, cardiac frequency, body temperature, as well as serum/ plasma concentrations of markers of stress (e.g. cortisol) or tissue injury (e.g. acute phase proteins), among others. Therefore, the objective of the present study was to review the main systemic markers of animal discomfort in sheep and cattle. Furthermore, we aimed to determine how reproductive procedures that have different degrees of invasiveness affect stress in sheep and cattle, and provide information that can help the implementation of strategies that limit animal discomfort.

\section{Stress, discomfort, and inflammation markers}

Understanding how stress and pain induce physiological and behavioral changes is fundamental to avoid causing stress and pain in animals. The classical response to stress is the activation of hypothalamus-pituitary-adrenal (HPA) axis, which is a survival mechanism to maintain homeostasis. However, there are also other acute behavioral changes, and changes in other markers that can help to determine the occurrence of discomfort more precisely. Identification of the most suitable markers and evaluation moments would help researchers design experiments to evaluate the impact of different procedures, and to develop alternatives to minimize the discomfort caused by such procedures.

\section{Systemic proteins used as stress and inflammation markers}

Total plasma protein is composed of albumin and globulins (alpha, beta, and gamma), and an albumin:globulin ratio of 1:1 is expected in healthy animals (KANEKO et al., 2008). Although an increase in the total plasma protein concentration is frequently associated with dehydration, inflammatory diseases play an important role in the regulation of total plasma protein concentrations. During inflammation and responses to stressful stimuli, a negative correlation between globulins and albumin is observed (ECKERSALL, 1995). Furthermore, changes in plasma concentrations of other proteins known as acute phase proteins (APP) are also observed, and an excellent review of APP in ruminants was published by CECILIANI et al. (2012).
APP are part of the innate immune response, and are immediately modulated to restore homeostasis after tissue injury caused by stimuli such as trauma, stress, inflammation, and neoplasia. When choosing systemic markers, it is important to consider that changes in the diet and in hepatic function, as well as vaccination and inflammation, can also modulate APP (CECILIANI et al., 2012). The acute phase response induces several systemic events such as fever, leukocytosis, and increases in cortisol concentrations, in addition to APP regulation (ECKERSALL, 1995; ECKERSALL, 2000). The concentration of positive APP is proportional to the degree of tissue injury or inflammation, and is inversely correlated to negative APP (KENT, 1992). Since changes in APP concentrations sometimes precede clinical symptoms, they are considered to be the first markers of pathological conditions. As such, the evaluation of APP concentrations may be useful in determining the impact of procedures performed in animals.

Haptoglobin is a high molecular weight positive APP described as a bacteriostatic acting in the defense against pathogens, and as an inhibitor of granulocytes activity. Haptoglobin is also known to have immunomodulatory effects (PETERSEN et al., 2004). In animals, serum haptoglobin concentrations increase after trauma, inflammation, bacterial infection, surgical procedures, and stressful conditions (MURATA \& MIYAMOTO, 1993; EARLEY \& CROWE, 2002). In ruminants, serum haptoglobin concentrations are sometimes not detected in healthy animals, but haptoglobin concentrations increase after the acute phase response (to $>2 \mathrm{~g} / \mathrm{L}$ ) approximately two days after stimulus (ECKERSALL et al., 2007). When using haptoglobin as a marker for stress, it is important to consider that the statistical analysis of data on serum haptoglobin concentrations may be impaired if some healthy animals present null values.

Serum amyloid (SA) is another highly sensitive positive APP used as a marker of inflammation, infection (HORADAGODA et al., 1999), and stress (ARTHINGTON et al., 2003) in ruminants, and SA is useful for the early diagnosis of these conditions. Although not commonly used, studies report a significant increase in concentrations of SA eight hours after the stimulus, with the maximum concentration of SA $(1000 \mathrm{mg} / \mathrm{L})$ reached between 24 and $48 \mathrm{~h}$ after the stimulus (KAJIKAWA et al., 1999). The SA concentrations can remain high in the chronic response to stressful stimuli, and, as such, SA is considered one of the APP with the widest range of response (GABAY \& KUSHNER, 1999). 
In contrast to APP that increase in concentration after stressful stimuli (positive APP), other proteins are down regulated during the acute phase response (negative APP). Albumin becomes a negative APP during acute processes and stressful conditions, as hepatocytes use it as a substrate to synthesize positive APP (KANEKO et al., 2008). Although there is significant variation between different species, serum albumin concentrations are usually between 2.5 and $4.5 \mathrm{~g} / \mathrm{dL}$ in healthy animals, and reductions in serum albumin concentrations of up to $50 \%$ may be observed after inflammatory processes (HAYASHI et al., 2001).

Paraoxonase 1 (PON1) is another negative APP synthesized by the liver and released in the bloodstream after the stimulus of pro-inflammatory cytokines (BIONAZ et al., 2007). After inflammatory and stressful stimuli, serum PON1 enzyme concentrations are reduced for approximately six hours after the stimulus (DE CAMPOS et al., 2017). In a study conducted in cattle, plasma PON1 concentrations in healthy animals were, on average, $83 \mathrm{U} / \mathrm{mL}$, and this decreased to $69 \mathrm{U} / \mathrm{mL}$ as a response to discomfort (BIONAZ et al., 2007; CECILIANI et al., 2012). In sheep, MINUTI et al. (2013) observed plasma PON1 concentrations of $130 \mathrm{U} / \mathrm{mL}$ in control animals, and PON1 concentrations decreased to less than $100 \mathrm{U} / \mathrm{mL}$ between 60 and $240 \mathrm{~min}$ after severe induced intestinal injury. Plasma concentrations of PON1 are variable depending on the technique used for quantification, and therefore the use of established thresholds and the comparison of values from different studies may not be appropriate.

In addition to APP, the evaluation of algiogenic substances, which sensitize nociceptors inducing pain, can also contribute to the identification of painful processes. These mediators are released after tissue injury, when there is an increase in arachidonic acid-derived eicosanoids such as prostaglandins and leukotrienes, which induce mastocyte degranulation. In ruminants, bradykinin was identified as a marker of inflammation and pain in milk samples from healthy cows $(120.7 \mathrm{pg} / \mathrm{mL})$ and from cows with mastitis (279.2pg/mL), using radioimmunoassay (ESHRAGHI et al., 1999). Another algiogenic factor is substance $\mathrm{P}$, which was characterized as an important indicator of pain and discomfort in livestock, because plasma concentrations of substance $\mathrm{P}$ were significantly higher 40min after surgical castration in calves $(506.4 \mathrm{pg} / \mathrm{mL})$ than in control calves $(386.4 \mathrm{pg} / \mathrm{mL})$ (COETZEE et al., 2008).

Other markers are also released in response to inflammatory stimuli, and may be useful when investigating the impacts of procedures on animals. For instance, in steers, the intravenous injection of lipopolysaccharide induces an inflammatory response with a peak in body temperature $\left(40.5^{\circ} \mathrm{C}\right)$ and an increase in respiratory rate five hours after injection (CARROLL et al., 2009). Increases in serum amyloid (SA), tumor necrosis factor alpha (TNF $\alpha$ ), and interleukin-6 (IL6) concentrations were also observed less than one hour after this stimulus, and remained high for up to six hours (CARROLL et al., 2009). Inflammatory reaction was accompanied by changes in serum cortisol concentrations, which peaked three hours after the challenge, and returned to baseline levels in eight hours, although both responses were influenced by cattle breed (CARROLL et al., 2009; CARROLL et al., 2011). Therefore, the evaluation of more than one APP and other parameters (clinical examination, serum/plasma cortisol concentrations, behavior, etc.) is required to provide more precise information, as each marker may be influenced by different factors.

\section{Evaluation of cortisol concentrations as an indicator} of stress

One of the main responses to stress is the release of glucocorticoids by the adrenal gland a few minutes after exposure to a stressful stimulus. Serum cortisol concentration is the most commonly used marker for pain and discomfort (BRETSCHNEIDER, 2005), and it is possible to analyze short-term effects of different procedures on the animals using serum cortisol concentrations. However, increases in cortisol concentrations are not exclusively mediated by painful stimuli, but also by responses to husbandry practices, excitation, and anxiety, and studies have demonstrated an increase in plasma cortisol concentrations approximately one hour after the stimulus.

Evaluation of cortisol concentrations usually involves restraining the animal during blood sample collection, which requires a trained professional, and the procedure itself can induce changes in cortisol concentrations. The evaluation of cortisol concentrations in fecal samples is a non-invasive alternative, and fecal concentrations can reflect plasma concentrations with a lag time of approximately 12 hours (PALME et al., 1996). Painful or stressful experiences can also be evaluated by an increase in salivary cortisol concentrations. However, although the same patterns are observed in saliva as in plasma, saliva cortisol concentrations are lower than those observed in plasma (NEGRAO et al., 2004). 
Effects of reproductive procedures on discomfort parameters

Efficiency of livestock production is influenced by reproductive efficiency. Using reproductive techniques, it is possible to increase the number of offspring from animals with high genetic merit. In addition, other procedures are performed to promote sterilization of genetically inferior animals. Regardless of the aim, reproductive techniques have to be efficient but must preserve animal welfare (MELLOR \& STAFFORD, 2000).

\section{Methods to sterilize male animals}

Castration is frequently performed to facilitate animal handling (as it reduces aggressiveness) and to increase fat deposition, and castration is the most studied procedure regarding the effects on markers of stress, pain, and inflammation (Table 1). In ruminants, several established castration techniques are available, and the choice depends on the circumstances (age, farm facilities, etc.) (CAPUCILLE et al., 2002), and on the legislation in each country or region. In general, negative effects such as violent reactions to castration and abnormal posture are less intense in younger animals (ROBERTSON et al., 1994).

In cattle, orchiectomy induces abnormal posture for up to $30 \mathrm{~min}$ after the procedure is completed (MOLONY et al., 1995). When performed at six, 21, and 42 days of age, the procedure induces peaks of cortisol concentrations reaching 106, 63, and $107 \mathrm{nmol} / \mathrm{L}$, respectively (ROBERTSON et al., 1994). When 14-month-old bulls were submitted to the surgical procedure (under local anesthesia), plasma haptoglobin concentrations peaked $(639 \mu \mathrm{g} /$ $\mathrm{mL}$ ) two days after the procedure, and remained elevated for up to four days. Regarding plasma cortisol concentrations, no significant changes were observed on days $0,1,2$, and 4 , whereas an increase in serum cortisol concentrations was observed on days 7 and 14 after the procedure (FISHER et al., 2001). The authors suggested that these late changes in cortisol concentrations were a response to the decrease in serum testosterone concentrations. Regarding acute effects, studies have demonstrated that serum cortisol concentrations peak at 30, 60 (OLIVEIRA et al., 2017), and 120min (MELÉNDEZ et al., 2017) after orchiectomy procedures, and no significant changes in PON1 activity and eye temperature were observed (OLIVEIRA et al., 2017). In lambs, surgical castration induced abnormal postures (for up to 150min) (MOLONY et al., 1993) and an increase in cortisol concentrations for at least four hours (LESTER et al., 1991). KENT et al. (1993) observed an increase in plasma cortisol concentrations from 40 to $180 \mathrm{~min}$ after lambs were subjected to castration procedures.

Impacts of castration using physical methods based on the blockade of testicular blood flow (rubber rings or bands and clamps) on the welfare of ruminants have also been studied. Although effective, some of these methods are not allowed, or have restricted use in many countries. Lambs submitted to rubber ring (RR) castration presented abnormal postures and restlessness in the first $45 \mathrm{~min}$ after the procedure was started, and these are the behavioral changes positively correlated with plasma cortisol concentrations (LESTER et al., 1996). MELCHES et al. (2007) observed that the use of emasculator techniques resulted in faster healing and less pain in the long-term, whereas RR induced discomfort equivalent to orchiectomy, with painful response to local palpation for up to 30 days. In cattle, PANG et al. (2006) observed that band castration induced an increase in plasma haptoglobin concentrations three days after the procedure. Regarding cortisol, band castration in cattle induced an increase in salivary cortisol concentrations for up to $120 \mathrm{~min}$ after the procedure, whereas no significant changes were observed in hair cortisol concentrations (chronic stress marker) on days 28 and 56 (MARTI et al., 2015). When one-month-old calves were submitted to surgical or band castration, MELÉNDEZ et al. (2017) did not observe significant changes in cortisol concentrations, but both methods induced a significant increase in cortisol concentrations in two and four month-old calves. In another study, similar salivary cortisol concentrations were observed in control and castrated calves when epidural anesthesia (xylazine) and flunixin meglumine were administered prior to the procedure (GONZÁLEZ et al., 2010).

Castration using intratesticular injection of substances that induce testicular atrophy is considered less invasive than band castration or orchiectomy (EMIR et al., 2008). Even though calves reacted to needle introduction, the injection of hydroxypropionic acid resulted in a lower plasma cortisol concentration three and six hours after the procedure compared to orchiectomy (COHEN et al., 1990). OLIVEIRA et al. (2017), using a solution with sodium chloride and lidocaine, did not detect changes in eye temperature in calves. Serum cortisol concentrations increased $30 \mathrm{~min}$ after injection $(1.8 \mu \mathrm{g} / \mathrm{dL}$ or $49.7 \mathrm{nmol} / \mathrm{L})$, and returned to baseline $60 \mathrm{~min}$ post-injection $(1.3 \mu \mathrm{g} / \mathrm{dL}$ or $35.9 \mathrm{nmol} / \mathrm{L}$ ), without changing serum PON1 activity.

As an alternative to circumvent the negative effects of the above-mentioned castration 
techniques, immunological castration was established as a minimally invasive procedure. Immunological castration is commercially available for cattle and swine. A recent study demonstrated that the vaccine used to castrate cattle is also effective in goats (LENTS et al., 2018). Most studies on immunological castration investigated the effects of this method on fertility, zootechnical performance, and carcass characteristics. In a study evaluating reactions to the vaccine in cows, an increase in body temperature was observed (for $24 \mathrm{~h}$ ), heart and respiratory rates increased (for up to $48 \mathrm{~h}$ ), and cattle responded to local palpation in the site of administration $(1 \mathrm{~mL}$ subcutaneous injection in the neck) for two to four weeks (BALET et al., 2014). Although cattle do react to the vaccine, which reduces food intake for a few days after treatment, a study comparing immunological and band castration in cattle reported no significant behavioral or physiological changes in vaccinated animals (MARTI et al., 2015).

In cattle, immunocastration (using four doses of the vaccine) significantly reduced testosterone concentrations and aggressiveness compared to non-castrated (control) animals. However, cortisol concentrations were higher in immuno-castrated cattle during slaughter compared to the cortisol concentrations observed 60 days before slaughter, and compared to intact bulls evaluated at the same time (SARABIA et al., 2018). The authors suggested that the increase in cortisol concentrations occurred because immuno-castrated animals were calmer and required more stimulus during the preslaughter handling.

\section{Semen collection by electroejaculation}

Electroejaculation (EE) is a technique used to obtain semen samples during breeding soundness evaluation from animals that are not trained for semen collection using artificial vagina, and EE is effective and causes penis protrusion, which allows penis evaluation (PALMER, 2005). The technique is considered stressful because it causes vocalization during the procedure. According to WHITLOCK et al. (2012), increased vocalization and a peak in plasma cortisol concentrations $(>100 \mathrm{nmol} / \mathrm{L})$ were observed in bulls $10 \mathrm{~min}$ after the beginning of the stimulus, with cortisol concentrations returning to baseline concentrations after $45 \mathrm{~min}(20 \mathrm{nmol} / \mathrm{L})$, compared to control bulls (i.e. bulls exposed to the equipment but without electric stimulus), whereas plasma substance $\mathrm{P}$ concentrations were not affected. None of the bulls submitted to EE attempted to lie down during the procedure.
In rams, EE allows to obtain ejaculates outside of the breeding season when there is a significant decrease in libido. In one study using rams, serum cortisol concentrations peaked (from $2.5 \mu \mathrm{g} / \mathrm{dL}$ or $69 \mathrm{nmol} / \mathrm{L}$ ) $20 \mathrm{~min}$ after the procedure, returning to baseline concentrations $(0.5 \mu \mathrm{g} / \mathrm{dL}$ or $13.8 \mathrm{nmol} / \mathrm{L}$ ) one hour later. Furthermore, the total plasma protein concentration increased significantly, from $5.8 \mathrm{~g} / \mathrm{dL}$, at the beginning of the stimulus, to $6.3 \mathrm{~g} / \mathrm{dL}$ at $30 \mathrm{~min}$ and $6.0 \mathrm{~g} / \mathrm{dL}$ at $120 \mathrm{~min}$, before returning to baseline concentrations. Vocalizations were more frequent between the second and fourth stimulus, and decreased after the seventh stimulus (DAMIAN \& UNGERFELD, 2011). To reduce the observed effects, ORIHUELA et al. (2009) suggested the administration (intramuscular) of ketamine and xylazine prior to the EE procedure.

To overcome the negative effects associated with EE in rams, the effectiveness of ultrasonic-guided massage of the accessory sex glands was evaluated. Although EE resulted in higher quality ejaculates, ultrasonic-guided massage was more advantageous regarding animal welfare: the semen collection procedure was faster and resulted in lower plasma cortisol concentrations $(25.3 \mathrm{ng} / \mathrm{mL}$ or $69.8 \mathrm{nmol} / \mathrm{L})$ compared to $\mathrm{EE}$ $(51.4 \mathrm{ng} / \mathrm{mL}$ or $141.8 \mathrm{nmol} / \mathrm{L}$ ) (UNGERFELD et al., 2015). Therefore, based on these previous studies, we concluded that the use of anesthesia prior to EE, and the development of alternative procedures may allow veterinarians to obtain ejaculates or semen samples with less discomfort to animals not trained for semen collection using an artificial vagina.

\section{Gynecological examination and reproductive} techniques in females

Reproductive tract manipulation, using rectal palpation and/or by vaginoscopy, is a common practice during gynecological examination aiming to evaluate genital health and determine the estrous cycle phase. Reproductive tract manipulation is also used to perform artificial insemination, pregnancy diagnosis, and diagnosis of pathologies. In one of the few studies that investigated the effects of these procedures, NAKAO et al. (1994) reported that performing vaginoscopy for $1.5 \mathrm{~min}$ in cows does not significantly alter plasma cortisol concentrations.

Among the reproductive techniques, artificial insemination (AI) is more frequently used to optimize genetic improvement, and pregnancy rates after the procedure are influenced by stress. According to NAKAO et al. (1994), transrectal palpation of the uterus and ovaries, as well as transcervical 
$1 \mathrm{AI}$, are considered stressful procedures because

2 they induce a plasma cortisol peak $(12 \mathrm{ng} / \mathrm{mL}$ or

$333.1 \mathrm{nmol} / \mathrm{L}$ ) as early as five minutes after AI, and

4 plasma cortisol concentrations return to baseline
( $8 \mathrm{ng} / \mathrm{mL}$ or $22.1 \mathrm{nmol} / \mathrm{L}) 25 \mathrm{~min}$ after AI (Table 1$)$. In beef cows submitted to timed AI (TAI), the insertion of intravaginal devices (IVD) resulted in a plasma cortisol concentration peak $(8.8 \mathrm{ng} / \mathrm{mL}$ or $24.3 \mathrm{nmol} / \mathrm{L})$

Table 1 - Effect of different reproductive procedures on systemic markers of discomfort, stress, and inflammation.

\begin{tabular}{|c|c|c|c|}
\hline Authors & Procedure & Sp. & Main results \\
\hline MARTIN et al. (1981) & Laparoscopy & $\mathrm{O}$ & $\begin{array}{c}\text { Cortisol peak }(60 \mathrm{ng} / \mathrm{mL} \text { or } 165.5 \mathrm{nmol} / \mathrm{L}) \text { after one laparoscopy and } \\
\text { concentrations between } 70 \text { to } 100 \mathrm{ng} / \mathrm{mL}(193.1 \text { to } 275.9 \mathrm{nmol} / \mathrm{L}) \text { after two } \\
\text { laparoscopic procedures }(12 \mathrm{~h} \text { interval). }\end{array}$ \\
\hline COHEN et al. (1990) & Chemical castration & $\mathrm{B}$ & Lower cortisol release after chemical castration compared to orchiectomy. \\
\hline LESTER et al. (1991) & Surgical castration & $\mathrm{O}$ & Cortisol increase up to $4 \mathrm{~h}$. \\
\hline KENT et al. (1993) & Surgical castration & $\mathrm{O}$ & Cortisol peak of $200 \mathrm{nmol} / \mathrm{L}$. \\
\hline NAKAO et al. (1994) & $\begin{array}{l}\text { Vaginoscopy and rectal } \\
\text { palpation }\end{array}$ & $\mathrm{B}$ & $\begin{array}{c}\text { Cortisol peak }(12 \mathrm{ng} / \mathrm{ml} \text { or } 33.1 \mathrm{nmol} / \mathrm{L}) \text { after uterine and ovarian palpation } \\
\text { or after AI. }\end{array}$ \\
\hline $\begin{array}{l}\text { ROBERTSON et al. } \\
\text { (1994) }\end{array}$ & Surgical castration & $\mathrm{B}$ & $\begin{array}{l}\text { Presence of abnormal posture and cortisol concentrations up to } \\
\qquad 107 \mathrm{nmol} / \mathrm{L} \text {. }\end{array}$ \\
\hline LESTER et al. (1996) & RR castration & $\mathrm{O}$ & Positive correlation between restlessness and cortisol concentrations. \\
\hline FISHER et al. (2001) & Surgical castration & $\mathrm{B}$ & Haptoglobin peak $(639 \mu \mathrm{g} / \mathrm{mL})$. \\
\hline $\begin{array}{l}\text { HOUDEAU et al. } \\
(2002)\end{array}$ & Cervical AI & $\mathrm{O}$ & Increased cortisol concentrations after $30 \mathrm{~min}$. \\
\hline $\begin{array}{l}\text { CHASTANT- } \\
\text { MAILLARD et al. } \\
(2003)\end{array}$ & Follicular aspiration & $\mathrm{B}$ & $\begin{array}{l}\text { Cortisol concentrations and leucogram values did not differ between cows } \\
\text { submitted to OPU and control cows. }\end{array}$ \\
\hline $\begin{array}{l}\text { STAFFORD et al. } \\
(2006)\end{array}$ & Laparoscopy & $\mathrm{O}$ & $\begin{array}{l}\text { Detomidine inhibited cortisol increase compared to ewes sedated with } \\
\text { acepromazin. }\end{array}$ \\
\hline PANG et al. (2006) & RR castration & $\mathrm{B}$ & Increase in haptoglobin concentrations three days after procedure. \\
\hline $\begin{array}{l}\text { MELCHES et al. } \\
(2007)\end{array}$ & EB castration & $\mathrm{O}$ & $\begin{array}{c}\text { Surgical castration induced higher cortisol concentrations compared to } \\
\mathrm{RR} \text { and emasculator. RR castration induces response to local palpation for } \\
\text { up to } 30 \text { days. }\end{array}$ \\
\hline PETYIM et al. (2007) & Follicular aspiration & $\mathrm{B}$ & Increase in cortisol concentrations up to $46 \mathrm{nmol} / \mathrm{L}$. \\
\hline $\begin{array}{l}\text { ORIHUELA et al., } \\
(2009)\end{array}$ & Electroejaculation & $\mathrm{O}$ & $\begin{array}{l}\text { The increase in cortisol concentrations and cardiac rate are consequences } \\
\text { of electric stimulus. }\end{array}$ \\
\hline $\begin{array}{l}\text { GONZÁLEZ et al. } \\
(2010)\end{array}$ & EB castration & $\mathrm{B}$ & $\begin{array}{l}\text { Epidural xylazine and intravenous flunixin inhibit salivary cortisol } \\
\text { increase. Chronic pain was not accompanied by changes in cortisol } \\
\text { concentrations. }\end{array}$ \\
\hline LONG et al. (2011) & TAI & $\mathrm{B}$ & $\begin{array}{c}\text { Cortisol increases }(8.8 \mathrm{ng} / \mathrm{mL} \text { or } 24.3 \mathrm{nmol} / \mathrm{L}) \text { after intravaginal device } \\
\text { insertion. }\end{array}$ \\
\hline $\begin{array}{l}\text { DAMIÁN \& } \\
\text { UNGERFELD (2011) }\end{array}$ & Electroejaculation & $\mathrm{O}$ & $\begin{array}{c}\text { Cortisol peak }(2.5 \mu \mathrm{g} / \mathrm{dL} \text { or } 69 \mathrm{nmol} / \mathrm{L}) \text {, increased TPP (up to } 6.3 \mathrm{~g} / \mathrm{dL} \text { ) and } \\
\text { vocalizations. }\end{array}$ \\
\hline $\begin{array}{l}\text { WHITLOCK et al. } \\
\text { (2012) }\end{array}$ & Electroejaculation & $\mathrm{B}$ & Cortisol peak (above $100 \mathrm{nmol} / \mathrm{L}$ ) and vocalizations. \\
\hline MARTI et al. (2015) & Immunocastration or EB & $\mathrm{B}$ & $\begin{array}{l}\text { Increase in salivary cortisol concentrations up to } 60 \text { and } 120 \mathrm{~min} \text { after anti- } \\
\text { GnRH vaccination and EB castration, respectively. }\end{array}$ \\
\hline $\begin{array}{l}\text { UNGERFELD et al. } \\
(2015)\end{array}$ & Electroejaculation & $\mathrm{O}$ & $\begin{array}{l}\text { Increase in cortisol concentrations after electroejaculation compared to } \\
\text { accessory glands massage. }\end{array}$ \\
\hline $\begin{array}{l}\text { MELÉNDEZ et al. } \\
\text { (2017) }\end{array}$ & Surgical castration or EB & $\mathrm{B}$ & $\begin{array}{l}\text { Increase in cortisol concentrations for } 120 \mathrm{~min} \text { after surgical or EB } \\
\text { castration. }\end{array}$ \\
\hline $\begin{array}{l}\text { OLIVEIRA et al. } \\
(2017)\end{array}$ & Surgical castration & $\mathrm{B}$ & $\begin{array}{l}\text { Increase in cortisol concentrations for } 60 \mathrm{~min} \text { and increase in scrotal } \\
\text { temperature. }\end{array}$ \\
\hline $\begin{array}{l}\text { OLIVEIRA et al. } \\
\text { (2017) }\end{array}$ & Chemical castration & $\mathrm{B}$ & Cortisol peak $(1.8 \pm 0.2 \mu \mathrm{g} / \mathrm{dL}$ or $5 \mathrm{nmol} / \mathrm{L})$ only after $30 \mathrm{~min}$. \\
\hline $\begin{array}{l}\text { OLIVEIRA et al. } \\
(2018)\end{array}$ & ET & $\mathrm{O}$ & $\begin{array}{l}\text { Increase in haptoglobin concentrations from three to six days and TPP } \\
\text { nine days after procedures. }\end{array}$ \\
\hline $\begin{array}{l}\text { KASIMANICKAM et } \\
\text { al. (2018) }\end{array}$ & ET & $\mathrm{B}$ & $\begin{array}{l}\text { Positive correlation between cortisol and substance P concentrations in } \\
\text { embryo recipient cows. }\end{array}$ \\
\hline
\end{tabular}

Sp: species; AI: artificial insemination; O: ovine; B: bovine; RR: rubber ring; OPU: ovum-pick up; EB: elastic band; TAI: timed AI; ET: embryo transfer; TPP: total plasma protein. 
five hours after inserting the IVDs, and cortisol concentrations returned to baseline $(1.3 \mathrm{ng} / \mathrm{mL}$ or $3.6 \mathrm{nmol} / \mathrm{L}$ ) two hours later (LONG et al., 2011). When performing cervical AI in ewes, HOUDEAU et al. (2002) observed a cortisol peak 30min after AI, and no significant differences were observed between ewes submitted to easy and difficult AI procedures. However, it is important to note that the authors used the values from the first blood collection as a reference, and did not include a control group. As such, it was not possible to isolate the effects of AI on cortisol concentrations in ewes.

In order to enable the use of frozen semen for AI in ewes, intrauterine deposition must be performed, which is usually achieved by laparoscopy. To our knowledge, the only studies investigating the impact of laparoscopy for ovarian evaluation in ewes focus on laparoscopy without the AI procedure. In one study, plasma cortisol concentrations increased temporarily $(60 \mathrm{ng} / \mathrm{mL}$ or $165.5 \mathrm{nmol} / \mathrm{L})$ four hours after one laparoscopic procedure, and plasma cortisol concentrations decreased eight hours after the procedure. When a second laparoscopy was performed 12 hours after the first, plasma cortisol concentrations immediately increased, and did not return to baseline levels, remaining between 70 and $100 \mathrm{ng} / \mathrm{mL}(193.1$ and $275.9 \mathrm{nmol} / \mathrm{L}$ ) until the last evaluation, $36 \mathrm{~h}$ after the procedure (MARTIN et al., 1981). Except for research purposes (i.e. to determine the moment of ovulation), there is no reason to perform two laparoscopic procedures in such a short timeframe. Furthermore, in the same study, AI was not performed and, since the procedure involves abdominal insufflation, uterine manipulation, and perforation for semen deposition, procedures including AI may induce more changes compared to only the laparoscopy. The fact that all the ewes were submitted to laparoscopy, and the study did not include a negative control group (i.e. ewes submitted only to restraining and blood collection), does not allow us to isolate the effect of different steps of the procedure.

To minimize the discomfort caused by laparoscopy, STAFFORD et al. (2006) demonstrated that detomidine (an analgesic and sedative) administration, 20min prior to the procedure, inhibits cortisol increase, whereas the use of only acepromazine caused a cortisol increase for up to $20 \mathrm{~min}$, before cortisol concentrations returned to baseline (pre-procedure) levels. In this study, the authors investigated only the immediate effects of laparoscopy without AI, and blood samples were collected only until three hours after the procedure. Since laparoscopy is a surgical procedure, postoperatory evaluations would also be necessary.
Although less frequent than AI, techniques for in vivo and in vitro embryo production are also performed in ruminants. Transvaginal ultrasoundguided ovarian follicular aspiration (ovum pickup; OPU) aims to retrieve oocytes for in vitro embryo production in cattle. Even though the OPU procedure is performed under epidural anesthesia, it represents a potentially stressful procedure. In heifers, plasma cortisol concentrations that were on average $5.7 \mathrm{nmol} / \mathrm{L}$ before the procedure, significantly increased after restraining and epidural anesthesia, remaining high $(46 \mathrm{nmol} / \mathrm{L}$ on average) until 10min after OPU. The heifers stopped eating during restraint, and reacted at the moment of needle insertion for epidural anesthesia, but no vocalizations or ataxia were observed (PETYIM et al., 2007). Plasma cortisol concentrations increased after each session in cows submitted to two weekly procedures (for eight weeks), including in control cows, which were submitted to exactly the same procedure except for ovarian perforation (CHASTANT-MAILLARD et al., 2003). These data reinforce the need for negative control groups and the evaluation of several markers, since, in some cases, depending on an animal's previous experiences, the handling itself may represent a stressful stimulus.

During embryo transfer, KASIMANICKAM et al. (2018) observed lower pregnancy rates in recipient cows with excitable temperaments, and the authors reported a positive correlation between excitable temperament, and serum cortisol concentrations, and substance $\mathrm{P}$ concentrations. The administration of flunixin meglumine at the time of embryo transfer was efficient in increasing pregnancy rates in cows with excitable temperaments. It is not possible to conclude if the results are a consequence of decreased discomfort or due to luteolysis inhibition by the anti-inflammatory. However, results demonstrated that identification of critical steps during different procedures and the development of strategies to minimize discomfort in animals can simultaneously benefit the animal's welfare, farmers, veterinarians and reproductive specialists.

Embryo collection and transfer procedures in ewes are more complex than in cows, because the ovine cervix is more tortuous, and its lumen narrows towards the uterine body and, therefore, accessing the uterus is more difficult. To overcome this issue, access to the uterus is achieved through laparotomy. When evaluating two different methods of embryo recovery in ewes (laparotomy vs. cervical transposition; CT) on inflammatory markers, OLIVEIRA et al. (2018) concluded that, although CT is less invasive, both methods induce an inflammatory reaction. There was 
no significant difference between methods regarding serum concentrations of haptoglobin, total protein, fibrinogen, and PON1. However, both procedures resulted in increased serum concentrations of haptoglobin for three to six days after the procedures, and total serum protein concentrations were increased for nine days after the procedures. Because $\mathrm{CT}$ is less invasive and, consequently, has a lower risk of negative side effects, this technique should be the first choice in those females in which cervical conformation is adequate for transposition.

\section{CONCLUSION}

Although several markers of stress, pain, and inflammatory reactions have been validated in sheep and cattle, few studies have investigated the effect of reproductive procedures on systemic markers. Furthermore, the lack of control groups in some studies also restricts the interpretation of obtained results. Even though there are limitations and variability due to the need of restraint for blood sample collection, serum or plasma cortisol concentrations are the most commonly used marker to evaluate stressful conditions, and analysis of cortisol concentrations in feces and saliva provides a suitable alternative to minimize the effect of sample collection. Therefore, the analysis of samples obtained from animals that were not submitted to the procedures, and the combined evaluation of different markers are needed to more precisely determine the impact of reproductive procedures on animals.

Once the negative effects and critical points of each procedure are determined, novel strategies can be developed to minimize the discomfort experienced by animals undergoing the procedure. For instance, in ruminants, the effects of different castration methods were extensively investigated because these procedures are widely performed and may have negative effects. The obtained knowledge was successfully applied to develop the immunocastration technique, a minimally invasive procedure that is now commercially available for swine and cattle. In this regard, validation in other species such as goats and sheep would contribute to significantly decrease the number of invasive procedures.

\section{DECLARATION OF CONFLICTING INTERESTS}

The authors declare no conflict of interest. The founding sponsors had no role in the design of the study; in the collection, analyses, or interpretation of data; in the writing of the manuscript, and in the decision to publish the results.

\section{ACKNOWLEDGEMENTS}

The authors are thankful to Fundação de Amparo à Pesquisa do Estado do Rio Grande do Sul (Fapergs) and Conselho Nacional de Desenvolvimento Científico e Tecnológico $(\mathrm{CNPq})$. This study was financed in part by the Coordenação de Aperfeiçoamento de Pessoal de Nível Superior - Brasil (CAPES) - Finance Code 001. B.G. Gasperin received a Productivity Fellowship from the CNPq (309138/2017-5).

\section{AUTHORS' CONTRIBUTIONS}

The authors contributed equally to the manuscript.

\section{REFERENCES}

ARTHINGTON, J. D., et al. Effect of transportation and commingling on the acute-phase protein response, growth, and feed intake of newly weaned beef calves. J Anim Sci, v.81, n.5, p.1120-1125, 2003. Available from: <https://www.ncbi.nlm. nih.gov/pubmed/12772837>. Accessed: Feb. 01, 2018. doi: $10.2527 / 2003.8151120 x$.

BALET, L., et al. Immunization against gonadotropin-releasing hormone in dairy cattle: Antibody titers, ovarian function, hormonal levels, and reversibility. J Dairy Sci, v.97, n.4, p.2193-2203, 2014. Available from: <http://www.sciencedirect.com/science/ article/pii/S0022030214001350>. Accessed: Feb. 01, 2018. doi: $10.3168 /$ jds.2013-7602.

BENNETT, R. M.; R. J. BLANEY. Estimating the benefits of farm animal welfare legislation using the contingent valuation method. Agricultural Economics, v.29, n.1, p.85-98, 2003. Available from: <https:/www.sciencedirect.com/science/article/ pii/S0169515003000379>. Accessed: Feb. 01, 2018. doi: 10.1016/ S0169-5150(03)00037-9.

BIONAZ, M., et al. Plasma paraoxonase, health, inflammatory conditions, and liver function in transition dairy cows. J Dairy Sci, v.90, n.4, p.1740-1750, 2007. Available from: <https://www.ncbi. nlm.nih.gov/pubmed/17369214>. Accessed: Feb. 01, 2018. doi: $10.3168 /$ jds.2006-445.

BLACHE, D.; S. K. MALONEY. New physiological measures of the biological cost of responding to challenges. Advances in Sheep Welfare, v.1, p.73-104, 2017. Available from: <https://www. sciencedirect.com/science/article/pii/B9780081007181000054>. Accessed: Feb. 01, 2018. doi: 10.1016/B978-0-08-100718-1.00005-4.

BRETSCHNEIDER, G. Effects of age and method of castration on performance and stress response of beef male cattle: A review. Livestock Production Science, v.97, n.2-3, p.89-100, 2005. Available from: <http:/www.sciencedirect.com/science/article/pii/ S0301622605001429>. Accessed: Feb. 01, 2018. doi: 10.1016/j. livprodsci.2005.04.006.

CAPUCILLE, D. J., et al. Castration in cattle: techniques and animal welfare issues. Compendium, v.24, n.9, p.66-73, 2002. Available from: <http://cmapspublic.ihmc.us/rid=1M8TBX9H12VBJGB-23QJ/Different $\% 20$ Castration $\% 20$ Techniques $\% 20$ and\%20Welfare\%20Issues.pdf>. Accessed: Feb. 01, 2018.

CARROLL, J. A., et al. Differential acute phase immune responses by Angus and Romosinuano steers following an 
endotoxin challenge. Domest Anim Endocrinol, v.41, n.4, p.163-173, 2011. Available from: <https://www.ncbi.nlm.nih.gov/ pubmed/21865005>. Accessed: Feb. 01, 2018. doi: 10.1016/j. domaniend.2011.06.002.

CARROLL, J. A., et al. Profile of the bovine acute-phase response following an intravenous bolus-dose lipopolysaccharide challenge. Innate Immun, v.15, n.2, p.81-89, 2009. Available from: $<$ https:// www.ncbi.nlm.nih.gov/pubmed/19318418>. Accessed: Feb. 01, 2018. doi: $10.1177 / 1753425908099170$.

CECILIANI, F., et al. Acute phase proteins in ruminants. J Proteomics, v.75, n.14, p.4207-4231, 2012. Available from: $<$ https://www.ncbi.nlm.nih.gov/pubmed/22521269>. Accessed: Feb. 01, 2018. doi: 10.1016/j.jprot.2012.04.004.

CHASTANT-MAILLARD, S., et al. Consequences of transvaginal follicular puncture on well-being in cows. Reproduction, v.125, n.4, p.555-563, 2003. Available from: <https://www.ncbi.nlm.nih. gov/pubmed/12683926>. Accessed: Feb. 01, 2018. doi: 10.1530/ rep. 0.1250555

COETZEE, J. F., et al. Plasma concentrations of substance $\mathrm{P}$ and cortisol in beef calves after castration or simulated castration. Am J Vet Res, v.69, n.6, p.751-762, 2008. Available from: <https:// www.ncbi.nlm.nih.gov/pubmed/18518655>. Accessed: Feb. 01, 2018. doi: 10.2460/ajvr.69.6.751.

COHEN, R., et al. Efficacy and stress of chemical versus surgical castration of cattle. Canadian Journal of Animal Science, v.70, n.4, p.1063-1072, 1990. Available from: <http://www.nrcresearchpress. com/doi/10.4141/cjas90-129\#.W8pa4hNKh1M $>$. Accessed: Feb. 01, 2018. doi: 10.4141/cjas90-129.

DAMIAN, J. P.; R. UNGERFELD. The stress response of frequently electroejaculated rams to electroejaculation: hormonal, physiological, biochemical, haematological and behavioural parameters. Reprod Domest Anim, v.46, n.4, p.646-650, 2011. Available from: <https:// www.ncbi.nlm.nih.gov/pubmed/21092067>. Accessed: Feb. 01, 2018. doi: 10.1111/j.1439-0531.2010.01722.x.

DE CAMPOS, F. T., et al. The acute effect of intravenous lipopolysaccharide injection on serum and intrafollicular HDL components and gene expression in granulosa cells of the bovine dominant follicle. Theriogenology, v.89, p.244-249, 2017. Available from: $<$ https://www.ncbi.nlm.nih.gov/pubmed/28043358>. Accessed: Feb. 01, 2018. doi: 10.1016/j.theriogenology.2016.11.013.

EARLEY, B.; M. A. CROWE. Effects of ketoprofen alone or in combination with local anesthesia during the castration of bull calves on plasma cortisol, immunological, and inflammatory responses. J Anim Sci, v.80, n.4, p.1044-1052, 2002. Available from: <https:// www.ncbi.nlm.nih.gov/pubmed/12002311>. Accessed: Feb. 01, 2018. doi: $10.2527 / 2002.8041044 x$.

ECKERSALL, P. Acute phase proteins as markers of inflammatory lesions. Comparative Haematology International, v.5, n.2, p.9397, 1995. Available from: <https://link.springer.com/article/10.1007/ BF00638925>. Accessed: Feb. 01, 2018. doi: 10.1007/BF00638925.

ECKERSALL, P. Acute phase proteins as markers of infection and inflammation: monitoring animal health, animal welfare and food safety. Irish Veterinary Journal, v.53, n.6, p.307-311, 2000.

ECKERSALL, P. D., et al. Acute phase protein response in an experimental model of ovine caseous lymphadenitis. BMC Vet
Res, v.3, n.1, p.35, 2007. Available from: <https://www.ncbi. nlm.nih.gov/pubmed/18093286>. Accessed: Feb. 01, 2018. doi: $10.1186 / 1746-6148-3-35$

EMIR, L., et al. Chemical castration with intratesticular injection of $20 \%$ hypertonic saline: A minimally invasive method. Urologic Oncology: Seminars and Original Investigations, v.26, n.4, p.392-396, 2008. Available from: <http://www.sciencedirect.com/ science/article/pii/S1078143907001378>. Accessed: Feb. 01, 2018. doi: 10.1016/j.urolonc.2007.05.013.

ESHRAGHI, H. R., et al. The release of bradykinin in bovine mastitis. Life Sci, v.64, n.18, p.1675-1687, 1999. Available from: $<$ https://www.ncbi.nlm.nih.gov/pubmed/10328527>. Accessed: Feb. 01, 2018. doi: 10.1016/S0024-3205(99)00105-8.

FISHER, A. D., et al. Effects of surgical or banding castration on stress responses and behaviour of bulls. Aust Vet J, v.79, n.4, p.279-284, 2001. Available from: <https://www.ncbi.nlm.nih.gov/ pubmed/11349415>. Accessed: Feb. 01, 2018. doi: 10.1111/j.17510813.2001.tb11981.x.

GABAY, C.; I. KUSHNER. Acute-phase proteins and other systemic responses to inflammation. N Engl J Med, v.340, n.6, p.448-454, 1999. Available from: <https://www.ncbi.nlm.nih. gov/pubmed/9971870>. Accessed: Feb. 01, 2018. doi: 10.1056/ NEJM199902113400607.

GONZÁLEZ, L. A., et al. Pain mitigation after band castration of beef calves and its effects on performance, behavior, Escherichia coli, and salivary cortisol. J Anim Sci, v.88, n.2, p.802-810, 2010. Available from: <http://dx.doi.org/10.2527/jas.2008-1752>. Accessed: Feb. 01, 2018. doi: 10.2527/jas.2008-1752.

HAYASHI, S., et al. A comparison of the concentrations of C-reactive protein and alpha1-acid glycoprotein in the serum of young and adult dogs with acute inflammation. Vet Res Commun, v.25, n.2, p.117-126, 2001. Available from: <https://www.ncbi. nlm.nih.gov/pubmed/11243653>. Accessed: Feb. 01, 2018. doi: 10.1023/A:1006404902214

HEID, A.; U. HAMM. Animal welfare versus food quality: factors influencing organic consumers' preferences for alternatives to piglet castration without anaesthesia. Meat Sci, v.95, n.2, p.203-211, 2013. Available from: <https://www.ncbi.nlm.nih.gov/pubmed/23743030>. Accessed: Feb. 01, 2018. doi: 10.1016/j.meatsci.2013.04.052.

HORADAGODA, N., et al. Acute phase proteins in cattle: discrimination between acute and chronic inflammation. The Veterinary Record, v.144, n.16, p.437-441, 1999. Available from: $<$ https://veterinaryrecord.bmj.com/content/144/16/437>. Accessed: Feb. 01, 2018. doi: 10.1136/vr.144.16.437

HOUDEAU, E., et al. Plasma levels of cortisol and oxytocin, and uterine activity after cervical artificial insemination in the ewe. Reprod Nutr Dev, v.42, n.4, p.381-392, 2002. Available from: $<$ https://www.ncbi.nlm.nih.gov/pubmed/12510878>. Accessed: Feb. 01, 2018. doi: 10.1051/rnd:2002033.

KAJIKAWA, T., et al. Changes in concentrations of serum amyloid A protein, a 1-acid glycoprotein, haptoglobin, and C-reactive protein in feline sera due to induced inflammation and surgery. Veterinary immunology and immunopathology, v.68, n.1, p.91-98, 1999. Available from: <https://www.ncbi.nlm.nih.gov/ pubmed/10231954>. Accessed: Feb. 01, 2018. doi: 10.1016/ S0165-2427(99)00012-4.

Ciência Rural, v.48, n.12, 2018. 
KANEKO, J. J., et al. Clinical biochemistry of domestic animals: Academic press. 2008.

KASIMANICKAM, R. K., et al. Flunixin meglumine improves pregnancy rate in embryo recipient beef cows with an excitable temperament. Theriogenology, v.107, p.70-77, 2018. Available from: $<$ https://www.ncbi.nlm.nih.gov/pubmed/29132037>. Accessed: Jul. 01, 2018. doi: 10.1016/j.theriogenology.2017.10.043.

KENT, J. Acute phase proteins: their use in veterinary diagnosis. British Veterinary Journal, v.148, n.4, p.279-282, 1992. Available from: $<$ https://www.ncbi.nlm.nih.gov/pubmed/1379866>. Accessed: Feb. 01, 2018. doi: 10.1016/0007-1935(92)90081-B.

KENT, J. E., et al. Changes in plasma cortisol concentration in lambs of three ages after three methods of castration and tail docking. Research in Veterinary Science, v.55, n.2, p.246-251, 1993. Available from: <http://www.sciencedirect.com/science/ article/pii/003452889390088W >. Accessed: Feb. 01, 2018. doi: 10.1016/0034-5288(93)90088-W.

LENTS, M. P., et al. Immunocastration of goats using antigonadotrophin releasing hormone vaccine. Theriogenology, v.114, p.7-13, 2018. Available from: <http://www.sciencedirect. com/science/article/pii/S0093691X18300943>. Accessed: Jul. 01, 2018. doi: 10.1016/j.theriogenology.2018.03.013.

LESTER, S., et al. Cortisol responses of young lambs to castration and tailing using different methods. New Zealand Veterinary Journal, v.39, n.4, p.134-138, 1991. Available from: <https:// www.ncbi.nlm.nih.gov/pubmed/16031640>. Accessed: Feb. 01, 2018. doi: 10.1080/00480169.1991.35680.

LESTER, S. J., et al. Behavioural and cortisol responses of lambs to castration and tailing using different methods. New Zealand Veterinary Journal, v.44, n.2, p.45-54, 1996. Available from: $<$ https://doi.org/10.1080/00480169.1996.35933>. Accessed: Feb. 01, 2018. doi: 10.1080/00480169.1996.35933.

LONG, S. T., et al. Plasma cortisol concentrations after CIDR insertion in beef cows. Reprod Domest Anim, v.46, n.1, p.181-184, 2011 Available from: <https://www.ncbi.nlm.nih.gov/pubmed/20403126>. Accessed: Feb. 01, 2018. doi: 10.1111/j.1439-0531.2010.01611.x.

MARTI, S., et al. Effect of anti-gonadotropin-releasing factor vaccine and band castration on indicators of welfare in beef cattle. J Anim Sci, v.93, n.4, p.1581-1591, 2015. Available from: <https:// www.ncbi.nlm.nih.gov/pubmed/26020180>. Accessed: Feb. 01, 2018. doi: $10.2527 /$ jas.2014-8346.

MARTIN, G. B., et al. Effect of stress due to laparoscopy on plasma cortisol levels, the preovulatory surge of $\mathrm{LH}$, and ovulation in the ewe. Theriogenology, v.16, n.1, p.39-44, 1981. Available from: <http://www.sciencedirect.com/science/ article/pii/0093691X81901114>. Accessed: Feb. 01, 2018. doi: 10.1016/0093-691x(81)90111-4.

MELCHES, S., et al. Castration of lambs: A welfare comparison of different castration techniques in lambs over 10 weeks of age. The Veterinary Journal, v.173, n.3, p.554-563, 2007. Available from: $<$ http://www.sciencedirect.com/science/article/pii/ S1090023306000165>. Accessed: Feb. 01, 2018. doi: 10.1016/j. tvj1.2006.01.006.

MELÉNDEZ, D. M., et al. Effect of band and knife castration of beef calves on welfare indicators of pain at three relevant industry ages: I. Acute pain1. J Anim Sci, v.95, n.10, p.4352-4366, 2017. Available from: <http://dx.doi.org/10.2527/jas2017.1762>. Accessed: Feb. 01, 2018. doi: 10.2527/jas2017.1762.

MELLOR, D. J. Operational Details of the Five Domains Model and Its Key Applications to the Assessment and Management of Animal Welfare. Animals (Basel), v.7, n.8, p.60. 2017, Available from: $<$ https://www.ncbi.nlm.nih.gov/pubmed/28792485>. Accessed: Feb. 01, 2018. doi: 10.3390/ani7080060.

MELLOR, D. J.; K. J. STAFFORD. Acute castration and or tailing distress and its alleviation in lambs. $\mathbf{N} \mathbf{Z}$ Vet $\mathbf{J}$, v.48, n.2, p.33-43, 2000. Available from: <https://www.ncbi.nlm. nih.gov/pubmed/16032116>. Accessed: Feb. 01, 2018. doi: 10.1080/00480169.2000.36156.

MINUTI, A., et al. Assessment of gastrointestinal permeability by lactulose test in sheep after repeated indomethacin treatment. $\mathbf{J}$ Anim Sci, v.91, n.12, p.5646-5653, 2013. Available from: <https:// www.ncbi.nlm.nih.gov/pubmed/24126268>. Accessed: Feb. 01, 2018. doi: 10.2527/jas.2013-6729.

MOLONY, V., et al. Behavioural responses of lambs of three ages in the first three hours after three methods of castration and tail docking. Research in Veterinary Science, v.55, n.2, p.236-245, 1993. Available from: <http://www.sciencedirect.com/science/ article/pii/003452889390087V>. Accessed: Feb. 01, 2018. doi: 10.1016/0034-5288(93)90087-V.

MOLONY, V., et al. Assessment of acute and chronic pain after different methods of castration of calves. Applied Animal Behaviour Science, v.46, n.1-2, p.33-48, 1995. Available from: <http:// www.sciencedirect.com/science/article/pii/0168159195006354>. Accessed: Feb. 01, 2018. doi: 10.1016/0168-1591(95)00635-4.

MURATA, H.; T. MIYAMOTO. Bovine haptoglobin as a possible immunomodulator in the sera of transported calves. British Veterinary Journal, v.149, n.3, p.277-283, 1993. Available from: $<$ https://www.ncbi.nlm.nih.gov/pubmed/8334509>. Accessed: Feb. 01, 2018. doi: 10.1016/S0007-1935(05)80173-3.

NAKAO, T., et al. Plasma cortisol response in dairy cows to vaginoscopy, genital palpation per rectum and artificial insemination. Zentralbl Veterinarmed A, v.41, n.1, p.1621, 1994. Available from: <https://www.ncbi.nlm.nih.gov/ pubmed/8085394>. Accessed: Feb. 01, 2018. doi: 10.1111/j.14390442.1994.tb00060.x.

NEGRAO, J. A., et al. Cortisol in saliva and plasma of cattle after ACTH administration and milking. J Dairy Sci, v.87, n.6, p.17131718, 2004. Available from: <https://www.ncbi.nlm.nih.gov/ pubmed/15453483>. Accessed: Feb. 01, 2018. doi: 10.3168/jds. S0022-0302(04)73324-X.

OLIVEIRA, F., et al. Inflammatory markers in ewes submitted to surgical or transcervical embryo collection. Small Ruminant Research, v.158, p.15-18, 2018. Available from: <https://www. sciencedirect.com/science/article/pii/S0921448817303085>. Accessed: Jul. 01, 2018. doi: 10.1016/j.smallrumres.2017.11.012.

OLIVEIRA, F. C., et al. Chemical castration in cattle with intratesticular injection of sodium chloride: Effects on stress and inflammatory markers. Theriogenology, v.90, p.114119, 2017. Available from: <https://www.ncbi.nlm.nih.gov/ pubmed/28166957>. Accessed: Feb. 01, 2018. doi: 10.1016/j. theriogenology.2016.12.001. 
ORIHUELA, A., et al. Breaking down the effect of electroejaculation on the serum cortisol response, heart and respiratory rates in hair sheep (Ovis aries). Journal of Animal and Veterinary Advances, v.8, n.10, p.1968-1972, 2009. Available from: <http:// medwelljournals.com/abstract/?doi=javaa.2009.1968.1972>. Accessed: Feb. 01, 2018.

PALME, R., et al. Excretion of infused 14C-steroid hormones via faeces and urine in domestic livestock. Animal Reproduction Science, v.43, n.1, p.43-63, 1996. Available from: <https://www. sciencedirect.com/science/article/pii/0378432095014586> Accessed: Feb. 01, 2018. doi: 10.1016/0378-4320(95)01458-6.

PALMER, C. W. Welfare aspects of theriogenology: Investigating alternatives to electroejaculation of bulls. Theriogenology, v.64, n.3, p.469-479, 2005. Available from: <http://www.sciencedirect. com/science/article/pii/S0093691X05001639>. Accessed: Feb. 01, 2018. doi: 10.1016/j.theriogenology.2005.05.032.

PANG, W. Y., et al. Effect of carprofen administration during banding or burdizzo castration of bulls on plasma cortisol, in vitro interferongamma production, acute-phase proteins, feed intake, and growth. J Anim Sci, v.84, n.2, p.351-359, 2006. Available from: <https://www. ncbi.nlm.nih.gov/pubmed/16424263>. Accessed: Feb. 01, 2018. doi: $10.2527 / 2006.842351 x$.

PETERSEN, H. H., et al. Application of acute phase protein measurements in veterinary clinical chemistry. Vet Res, v.35, n.2, p.163-187, 2004. Available from: <https://www.ncbi.nlm.nih. gov/pubmed/15099494>. Accessed: Feb. 01, 2018. doi: 10.1051/ vetres:2004002.

PETYIM, S., et al. Ovum Pick up in Dairy Heifers: Does it Affect Animal Well being? Reproduction in domestic animals, v.42, n.6, p.623-632, 2007. Available from: $<$ https://onlinelibrary.wiley. com/doi/abs/10.1111/j.1439-0531.2006.00833.x>. Accessed: Feb. 01, 2018. doi: 10.1111/j.1439-0531.2006.00833.x.
ROBERTSON, I. S., et al. Effect of different methods of castration on behaviour and plasma cortisol in calves of three ages. Res Vet Sci, v.56, n.1, p.8-17, 1994. Available from: <https://www.ncbi. nlm.nih.gov/pubmed/8146458>. Accessed: Feb. 01, 2018. doi: 10.1016/0034-5288(94)90189-9.

SARABIA, J., et al. Effect of immunocastration on behaviour and blood parameters (cortisol and testosterone) of Holstein bulls. Austral J Vet Sci v.50, p.77-81, 2018. Available from: <https:// scielo.conicyt.cl/scielo.php?script $=$ sci_arttext\&pid $=$ S071981322018000200077\&lng=es\&nrm=iso $>$. Accessed: Jul. 01, 2018. doi: 10.4067/S0719-81322018000200077.

SPOONER, J. M., et al. Attitudes of Canadian citizens toward farm animal welfare: A qualitative study. Livestock Science, v.163, p.150-158, 2014. Available from: $<$ https://www.sciencedirect.com/ science/article/abs/pii/S1871141314000985>. Accessed: Feb. 01, 2018. doi: 10.1016/j.livsci.2014.02.011.

STAFFORD, K. J., et al. Stress caused by laparoscopy in sheep and its alleviation. New Zealand Veterinary Journal, v.54, n.3, p.109-113, 2006. Available from: $<$ https://doi.org/10.1080/00480169.2006.366 21>. Accessed: Feb. 01, 2018. doi: 10.1080/00480169.2006.36621.

UNGERFELD, R., et al. Physiological responses and characteristics of sperm collected after electroejaculation or transrectal ultrasoundguided massage of the accessory sex glands in anesthetized mouflons (Ovis musimon) and Iberian ibexes (Capra pyrenaica). Theriogenology, v.84,n.7,p.1067-1074,2015.Available from: <http:// www.sciencedirect.com/science/article/pii/S0093691X15003143>. Accessed: Feb. 01, 2018. doi: 10.1016/j.theriogenology.2015.06.009.

WHITLOCK, B. K., et al. Electroejaculation increased vocalization and plasma concentrations of cortisol and progesterone, but not substance P, in beef bulls. Theriogenology, v.78, n.4, p.737-746, 2012. Available from: <https://www.ncbi.nlm.nih.gov/pubmed/22537995>. Accessed: Feb. 01, 2018. doi: 10.1016/j.theriogenology.2012.03.020. 